\title{
J(৫)
}

Received: 29.05 .2020

Accepted: 01.06 .2020

Published: 14.06 .2020

\section{ÖZERTURAL, Z. Uigurisches Wörterbuch Sprachmaterial der vorislamischen türkischen Texte aus Zentralasien, Band 1 Verben, Teil 2: edäd- - iztä-, unter Mitwirkung von K. RÖHRBORN, Franz Steiner Verlag, Stuttgart, 2020, XXIII+148 pp. ISBN: 978-3-515-12613-7}

\author{
Erdem UçAR \\ Friedrich-Schiller-Universität Jena (Jena/Germany) \\ E-mail: erdem.ucar@uni-jena.de
}

Uigurisches Wörterbuch $(\rightarrow U W)$ projesini muhtemelen gerçek anlamda hayal eden ilk kişi müteveffa Uygurist A. von GABAIN olmuş, ama projeyi hayata geçirme işi talebesi RöHRBORN'a nasip olmuştur. GABAIN, projenin gerçekleştirilmesi için talebesine destek vermiş ve ikisi birlikte 1965 'ten itibaren projenin teorik zemini üzerine birçok defa görüşmeler gerçekleştirmiştir. RöHRBORN, 1970'li yıllarda UW projesini hayata geçirmek üzere Gießen'de kollarını sıvamış ve bunun sonucunda projenin ilk ürünü 1977'de gün yüzüne çıkmıştır. Daha sonra yıllar içinde sözlüğün diğer beș fasikülü daha yayımlanmıştır (Röhrborn 1979, 1981, 1987, 1994, 1998). Çift sütun şeklinde altı fasikül olarak çıkan sözlük toplam 446 sayfadir. 


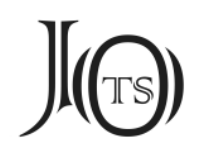

30 Nisan 1998'de, UW projesinin Göttingen Bilimler Akademisi tarafindan desteklenmesi kararının ardından RÖHRBORN, yeni projede akademinin uyarıları doğrultusunda sözlüğün işleyişinde önemli bir değişikliğe gitmiş ve sözlüğü Fiiller ve İsimler, Edatlar, Zamirler olmak üzere iki farklı cilt olarak neşretmeye karar vermiştir. Bunun ardından ilk olarak UW’nin fiiller cildi (Röhrborn 2010), daha sonra iki ciltlik isimler cildi (Röhrborn 2015, 2017) peş peşe neşredilmiştir. Tanıtımını yapacağımız yeni cilt ise filller serisinin ikinci cildidir.

Bu ciltte sözlüğün yazarı kısmında çok önemli bir değişiklik olmuş ve sözlügün yazarı olarak Zekine ÖZERTURAL'ın ismi konmuştur. UW projesinde 43 yıldır tek yazar ismiyle çıkan ve projeyi başlatan Klaus RöHRBORN'un adı bu ciltte “unter Mitwirkung” sıfatıyla ikinci sıraya geçmiş, yani onun ismi sözlüğün yazarı olarak yer almamıştır. Bu cilt, sözlüğün sunuş, hazırlanış veya yöntemi bakımından sözlüğün önceki neşirlerinden bir farklılık göstermemektedir. Bu nedenle, birinci yazar olarak proje sahibinin adının konmayışının şaşırtıcı olduğunu itiraf etmeliyim. Bu duruma göre, sözlüğün yazarı olarak kapaktaki ilk isim olan ÖzERTURAL'’n adını kabul etmek zorundayız.

Sözlüğün Giriş bölümünün "1. Verben und Verbalnomina" [Filler ve İsim-Fiiller] (s. IX-XI) başlıklı ilk kısmında, Eski Uygurcadaki isim-fiillerin özellikleri Erdal 2004 'ten faydalanılarak örneklerle açıklanmıştır. Buna göre, sözlükbirimleştiği kesin olmayan yapıların artık maddeleştirilmeyeceği ve isim-fiillerin ilgili fiil maddesi altında değerlendirileceği söylenmiştir. Aslında bu ilke UW'nin isimler cildinde zaten uygulanmıştı. Mesela, akmak $\rightarrow$ ak- (Röhrborn 2015: 81). Ancak bu tercihin bazı sorunları beraberinde getirdiği görülüyor. Mesela, ermeksizin erinöksüzin bışrun- 'sich üben ohne Überdruss und ohne Trägheit' ifadesi ér- yérmaddesi altında (s. 25) gösterilmiştir. Sözlükteki adlandırma ile ifade edilecek olunursa, ermeksiz artık lexikalisierte Verbalnomina hâlini almıştır. Dolayısıyla bunun ayrı bir sözlükbirim olarak maddeleştirilmesi icap etmektedir. Yazarın, ermeksiz'i ér- yér- maddesi altında zikretmesi sözlükçülük yöntemine uygun değildir, zira bir sözlükten beklenilen temel şey bütün sözlükbirimleri ayrı maddelerde kolaylıkla bulunmasına izin vermesidir. Yazar, lexikalisierte Verbalnomina 


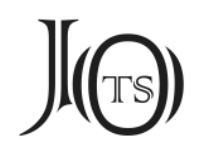

hâli kesinleşmeyenleri ayırmanın zor olduğunu düşünerek böyle bir yöntem izlemiştir. Bunlar ayrı bir maddede gösterilseydi karışıklık elbet daha az olacaktı. Sözlükte buna benzer maddeler için krş. éltmeki (s. 11), ıdmakta (s. 78), vs.

"2. Verben mit unklarer Etymologie und mit y-Prothese" [Kökeni Belirsiz Fiiller ve y-Türemesi] başlıklı ikinci kısmında (s. XI-XII) iki meseleye değinilmiştir.

İlk olarak bazı kelimelerin etimolojilerinin belli olmadı $\breve{g} 1$ ve bu nedenle okunuşlarının iki şekilde olabileceği söylenmiştir: ısır- isir- gibi. Yani, yazar maddelerdeki ikili gösterimin nedenini kelimelerin etimolojilerinin belirsizliğine bağlamıştır. Bir sözlükte aynı maddede iki şeklin gösterilmesinin pratikte faydası olacağı düşünülebilir, ancak bu uygulamanın sözlükçülükte kabul edilmediği bilinmektedir. Çünkü ideal bir sözlükte bir maddede tek bir sözlükbirimin olması umulur. Böylelikle okuyucunun ikileme düşmesi önlenebilir.

İkili biçimde verilen maddelerden biri olan ısır- isir- '1sırmak' (s. 95-96) maddesinde sadece bir yerden getirilen ön damak ünlülü isirmek tanığına dayanarak fiilin öndamak ünlülü varyantının olduğunun kabulü biraz şüphelidir. Nitekim yazarın sözlükte esas aldığı CLAUSON, maddeyi ısır- olarak göstermiştir (1972: 251b). Bugün Türk dillerinde kelimenin sadece arka damak ünlülü şekli yaşamaktadır (Radloff 1893: 1388-1389). Dolayısıyla CLAuson'un yaptı̆̆ı gibi kelimenin yaşayan Türk dillerindeki tanıklarından da faydalanarak ikili biçimlerde standart ve en yaygın olan biçiminin benimsenmesi daha doğru olacaktır. Ayrıca, tek bir yerde rastlanılan isirmek biçiminin Eski Uygurcadaki ağız sızıntılarından biri olabileceği de unutulmamalıdır.

İkinci mesele olarak, başta /y/'li ve /y/'siz biçime sahip kelimelerin kökenlerinin belirsiz olduğundan bahsedilmiştir. Köken belirsizliğinin /y/'li biçimlerle doğrudan ilgisi yoktur, zira Eki Türkçede kökeni şüpheli /y/'siz de olan pek çok kelime bulunur. Bahsedilen “y- ünsüzü türemesi” hakkında ciddi bir literatür olmasına rağmen yazarın bu literatürü dikkate almadığı görülmektedir. Baştaki /y/'li ve /y/'siz kelimelerin kaynağı hakkında şimdiye değin farklı görüşler sunulmuştur. Bu bölümde RAMSTEDT'in (1916: 66-84), LIGETI'nin (1938: 177-204), DoERFER'in (1981: 93-141; 1982: 138-168), TEKIN'in (1994: 51-66) ve ERDAL'1n (2004: 81- 


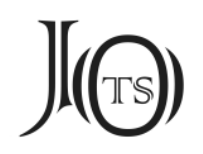

82) görüşlerine kısaca yer verilerek sözlükte benimsenen fikrin belirtilmesi beklenirdi. Ancak sözlükte böyle bir şeye girişilmemiş, sadece /y/'li biçimleri olan fiillerin maddelerde /y/'siz biçimlerle birlikte verileceği ifade edilmiştir. Bu tercih bazı sorunları doğurmuştur.

Mesela, ıçan-maddesinde (s. 68) kelimenin /y/'li biçimleri de olmasına rağmen madde başında sadece ıçan- gösterilmiştir. Tanık için verilen örneklerde /y/'li biçimlere rastlanmaktadır. Yazar, kelimenin kökeninin belirsiz olduğunu söylemiştir, ama çalışmada Tekin 1994 kullanılmış olsaydı, kelimenin kökeni için orada (1994: 54) önerilen bir köken teklifi de görülebilirdi. Aynı şekilde, ıra- ve urat-maddelerinde (s. 92-93) kelimelerin /y/'li biçimleri olmasına rağmen madde başında /y/'li şekiller gösterilmemiştir, üstelik ıra- maddesinde fiilin kökeninin Kaşgarî̀ye göre yıra-'ya dayandığı da belirtilmiştir. Eğer, /y/'li ve /y/'siz biçimler tek maddede verilecekse, bunun bütün örneklerde uygulanması gerekmektedir.

/y/'li ve /y/'siz biçimlerin hangisinin aslî olduğu konusunda sözlüğün benimsediği bir fikir olmadığ veya okuyucunun bunu sözlükten öğrenmesi mümkün olmadığı için bazı maddelerde karışıklık ortaya çıkmıştır. Mesela, Eski Uygurcada it- 'yitmek' fiilinin /y/'li biçimine rastlanmazken (s. 143), fiilin ettirgen gövdelerinin /y/'li biçimleri bulunmaktadır: ittür- yittür- (s. 144-146) ve itüryitür- (s. 146-147). Yazar, maddesinde /y/'li biçimi ikinci sırada göstermiştir, ama fiil Runik harfli yazıtlarda /y/'li olarak görülmektedir. Mesela, étit- $\rightarrow$ yétit- maddesinde (s. 65) kelimenin açıklaması yétit- maddesine havale edilmiştir. Bu tercih yazarın /y/'li biçimi aslî kabul ettiğini mi göstermektedir? Yine, *ırga- maddesinde (s. 93) " $\rightarrow$ yırga-" göndermesi vardır. Eğer * ırga- diye bir tanık Eski Uygurcada tespit edilmediyse bunun madde olarak gösterilmesi gerekli midir ya da * ırga- mı yoksa yırga- mı aslî biçimdir gibi bir soruya sözlükte cevap bulmak mümkün değildir. Benzer bir örnek de éltir- maddesidir (s. 15). Bu maddede ana maddenin yéltir- olduğu belirtilip o maddeye gönderme yapılmıştır. Okuyucu, sözlükte fiilin hangi biçiminin aslî olarak kabul edildiğini öğrenememektedir.

Sözlükte tekörnek olan kelimeler ayrıca vurgulanmamıştır, mesela énçik- (s. 20), ıpla- (s. 92), vs. Bunların vurgulanması Eski Türk leksikolojisi için oldukça değerlidir. Nitekim CLAUSON sözlüğünde bunları ayrıca mutlaka belirtmiştir. 


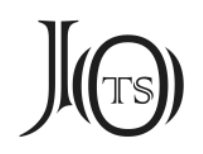

Girişin 3. kısmında Neue Abkürzungen [Yeni Kisaltmalar] (s. XIII) ve 4. kısminda da Neue Siglen und Kurztitel [Yeni Eser Kısaltmaları] (s. XIV-XVI) vardır. Kaynakça hakkında bazı noktalara değinmek istiyorum.

Sözlükte *ll- maddesinde (s. 87) Uçar 2017b kullanılıp zikredilmesine rağmen, sözlüğün kaynakçasında Uçar 2017b bulunmamaktadır. 799. sıradaki Kaçalin 2018 künyeli eser yayınlanmış gibi gösterilmiştir, ancak bu eser bildiğim kadarıyla henüz neşredilmemiştir.

Kaynakçada bir çalışma daha dikkatimi çekti. Hamilton 1971, UW'nin eski ve yeni serilerinde KP kısaltmasıyla kullanılmıştı. Bu ciltte de aynı şekilde devam edilmiştir. Mesela, én- maddesi (s. 16). Ancak buna rağmen yeni eklenen kaynaklar listesinde Hamilton 1971'in Türkçedeki iki tercümesinin daha yer aldığı görülmektedir. Sözlükte, daha çok Korkut-Birkan tercümesine başvurulduğu görülmektedir. Bir eserin hem aslının hem de iki tercümesinin kaynakçada yer alması biraz tuhaftır. Bazı yerlerde eserin aslının ve tercümelerinin beraber kullanımı karışıklı̆ga neden olmuştur. Mesela, égr(i)gş(e)l- maddesinde (s. 4) "Lesung von Korkut-Birkan" atfı vardır, ama maddede kullanılan bilginin kaynağı aslında HAMILTON'dur, onun eserinin çevirmenleri değildir. Üstelik aynı maddede hem eserin aslına hem de KORKUT-BiRKAN tarafından yapılan tercümesine atıf vardır (s. 5). Okuyucu burada iki farklı eserin olduğunu sanabilecektir. Diğer taraftan, $\imath d-$ maddesindeki açılamada (s. 70) Hamilton 1971, yani eserin Fransızca aslı kullanılmıştır. Kaynakların kullanımı açısından bu durum çelişkilidir.

Sözlükteki bazı maddeler hakkındaki küçük dikkatlerimi paylaşmak istiyorum.

édile- 'hükmetmek' (s. 3-4) ve édilet- 'bir şeyi başkasına devretmek' (s. 4) gövdeleri kapalı /é/'li gösterilmiştir, ama Eski Türkçede gövdenin kökü olan idi ‘sahip' kelimesinin /é/'li olduğunu gösteren bir delil bulunmaz. Maddede zaten kapalı /é/'li olduğunu gösteren bir yazım özelliğinden bahsedilmemiştir. Brāhmī ve Tibet harfli metinlerde de kelime /i/'lidir. Maddede zikredilmese de bu okunuşta muhtemelen DOERFER'in (1965: 636 [176-178]) tesirinde kalınmıştır. Sözlükte esas alınan CLAUSON sözlüğünde fiilin kökü idi olarak yer almıştır (1972: 41ab). Dolayısıyla iki maddenin idile- ve idilet- olarak düzeltilmesi doğru olacaktır. 


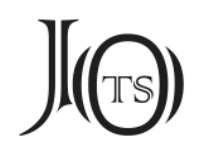

égr(i)gş(e)l-maddesinde (s. 5) kelimeye verilen 'her yandan burgaçlar oluşturmak, dalgalanmak (?)' anlamı net değildir, zira burgaç kelimesi bugün Türkçede bilinen ve yaygın olan bir kelime değildir. Bu kelime ağızlara aittir. Bunun yerine girdap kullanılması daha iyi olabilir.

élt- maddesinde (s. 7) kelimenin kökeni hakkında HAMILTON ve SEVORTYAN'in eserlerindeki cüretkâr tekliflere bakılması söylenmiş, ama onların ne söylediği gösterilmemiştir. Aslında yazar, HAMILTON'un sadece KP'nin dizinindeki köken önerisini görmüştür, ama HAMILTON farklı bir öneriyi başka bir eserinde ileri sürmüş ve ilet- (sic!) fiilinin aslının ület- (< üle-t-) 'pay etmek' olabileceğini iddia etmiştir (1986/I: 217b). Aynı öneri son olarak MoRIYASU tarafından da kabul edilmiştir (2019: 81). HAMILTON’un iki önerisinin pek de mantıksız olmadığını söylemeliyim.

énç ıd-maddesinde (s. 20) ibare için ıd-maddesine bakılması söylenmiştir, ancak bu tür birleşik yapılar sözlükte ayrıca maddeleştirilmediği için bu maddenin gerekliliği tartışmalıdır.

énçlentür-maddesinde (s. 20-21) fiile verilen 'birini rahat birakmak vb.' anlamı yanlış anlaşılmaya müsaittir. Bu tercüme, Almanca 'in Ruhe lassen usw.' anlamlandırmasının Türkçe karşılığını vermediği gibi Uygurca fiilin anlamını da karşılamaz. Fiilin Türkçe karşıllı̆ı ‘bir şeyi/birini huzura erdirmek' olmalıdır.

ér- 'bir şeye ait olmak, bağlı olmak' (s. 26) maddesi aslında UW'nin fiiller cildindeki er- (I) maddesine (Röhrborn 2010: 146-174) aittir, bu madde oraya aktarılmalıdır, yani ér- $\rightarrow$ er- (I) şeklinde gösterilmelidir. Nitekim benzer özellikteki bazı maddelerde bu yapılmıştır. Mesela, étiz- $\rightarrow$ etiz- (s. 65), vs.

érgür-maddesinde (s. 26) fiilin tanıklanmamış bir ér- 'ulaşmak' köküne dayandığı söylenmiştir, ancak bu kök Tunyukuk yazıtında (45) tanıklanmıştır.

érin- yerin- maddesindeki (s. 27) açılamada Róna-Tas-Berta 2011/I: 334'deki etimolojik notun dikkate alınması faydalı olabilir. Ayrıca, aynı maddede érin-'e verilen 'bir konuda, bir şahısta üzgün olmak' anlamlandırmasından Türkçede bir şey anlamak zor. Uygurcada fiil yönelme hali ile kullanılıyor ve fiile 'birine/ bir şeye kaygılanmak' anlamı verilebilir. 


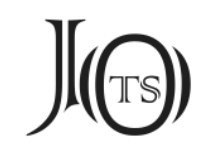

értür- maddesinde (s. 32) fiile verilen 'bir şeye karşı tiksindirmeye teşvik etmek' karşıllğından Türkçede bir şey anlaşılmıyor, fiil için 'tiksindirmek' anlamı yeterlidir.

ésil- maddesinde (s. 33) fiilin imlâsı hakkındaki açıklamada fiilin Dîvânu Lugâti't-Türk'teki yazımına da yer verilmesi faydalı olabilir, zira Kaşgarî fiili eysil(Dankoff-Kelly 1982/I: 139 [230]) olarak kaydetmiştir.

éşid- eşid-maddesinde (s. 36-38) fiilin yazım özellikleriyle ilgili olarak daha ziyade kelime başındaki ünlüsünün açık veya kapalı /e/'li olup olmadığı meselesi üzerinde durulmuştur. Bu konuda ERDAL, eşid-'in Runik harfli yazıtlarda, éşid-'in ise Uygurca metinlerde yaygın olduğunu söylemiştir (1991: 715). Ancak Eski Uygurcanın yazımında kullanılan yazı sistemlerinde fiilin bazen <t>li yazımı da görülüyor. Mesela, Brāhmī harfli metinlerde fiil éşit- okunacak şekilde yazılmıştır. Yazar, bu konuda bir açıklama yapmamıştır. Kanaatimce, Eski Türkçede éşideşid- yanında belki de fiilin éşit- eşit- biçimleri de vardı. Sözlük yazarı, kapalı /é/ konusunda Brāhmī harfli metinlerdeki tanıkları esas alıyorsa, /d/ ve /t/ ikileminin yaşandığı tanıklarda da <t>'li yazımları neden dikkate almadığını açıklamalıdır. Yazarın belki de burada UW'nin daha önceki cildinde ortaya konan "Dentalkonfusion” bozukluğun köken izahıyla düzeltileceği açıklamasına (Röhrborn 2010: XXIV-XXV) dayanarak bir izah getirmediği tahmin edilebilir. Ancak yazar maddede éşid- eşid- fiilinin kökeni için sadece sözlükbirimleşmiş veya dilbilgisilleşmiş bir yapı olduğunu söylemektedir. Eğer kelime böyleyse, fiilin kökünde bulunan ettirgenlik ekinin /t/'li mi yoksa /d/'li mi olduğu konusuna açıklık getirilmelidir.

isi- '1sınmak' maddesi (s. 128) ilginçtir, zira bu fiilin edilgen gövdesi için ésil'azalmak' maddesine (s. 33) bakılması söylenmiştir. Yani sözlüğe göre Eski Uygurcada isi- 'ssınmak' fiilinin edilgen gövdesi isil- bulunmamaktadır. Altun Yaruk'un XV. bölümünün ikinci kısmının neşrinde $\mathrm{AYSYL}^{1}$ imlâsına sahip isil- (Suv. 500/16) diye bir kelime tespit etmiştim (2017a: 132). Yanılmıyorsam bu tanık ilk kez benim tarafımdan tespit edilmiştir. Metinde isil- fiili çol- 'yakmak' ile beraber

\footnotetext{
1 Uygurca kelimelerin harfçevrimi için bk. Uçar 2020.
} 


\section{$J(\Theta)$}

kullanılmıştır. Buna göre, isi- fiilinin isil- şeklinde bir gövdesi olduğu bellidir ve madde olarak eklenmesi gerekmektedir.

isin- '1sınmak' maddesinde (s. 129) gösterilen 'çalışkan olmak, dikkatini yoğunlaştırmak, ilgilenmek' şeklindeki üçüncü anlam muhtemelen 'übertragene Bedeutung' olmalıdır.

ll- maddesinde (s. 87), Eski Uygurcada $l$ - diye bir kelimenin olmadığı ifade edilmiştir. Kutadgu Bilig ve Dîvânu Lugâti’t-Türk ekseninde Eski Türkçede ll- diye bir fiilin varlığından daha önce bahsedilmiştir (Erdal 2004: 54; Uçar 2017b: 128144). Eski Uygurca mektuplar üzerine çıan son neşirde U 5847 numaralı Uygurca parçada fiil ılmak 'alçalmak' olarak geçmektedir (Moriyasu 2019: 181). Dolayısıyla, yazarın Eski Uygurcada ll- diye bir kelime yoktur hükmü geçerliliğini yitirmektedir.

ırgal- maddesindeki (s. 94) açıklamada Róna-Tas-Berta 2011/I: 469'daki etimolojik notun dikkate alınması faydalı olabilir.

Eski Uygurca Daśakarmapathāvadānamālā tercümesine ait U 1548 numaralı parçada (B/6) ıtarlamak şeklinde geçen ve neşirde 'wiederholtes Stoßen' anlamı verilen (Wilkens 2016/I: 11948 [864]) kelimeye sözlükte yer verilmemiştir. Sözlükte ttarla- maddesinin bulunması ve kelimenin açıklanması gerekmektedir.

iç- maddesindeki (s. 97) açıklamada Róna-Tas-Berta 2011/I: 341'deki etimolojik notun dikkate alınması faydalı olabilir.

igele-'nin 'yönetmek' (s. 108) Eski Uygurcadaki farklı imlâları gerçekten ilgi çekicidir. Fiil, bazı metinlerde AYALA- ve AY ALA- şeklinde yazılmıştır. Yazar, bu tür imlâlara bakarak kelimenin iele- şeklinde, yani ikiz ünlülü olarak okunabileceğini düşünmektedir (s. 97). Belki de bu görüş Erdal 2004: 122'deki tespite dayanmaktadır. Aslında AYALA- imlâsı kelimenin eyele- şeklinde okunmasına da imkân tanımaktadır. Fiilin kökü ige 'sahip' kelimesi olup üzerine $\{+1 \mathrm{~A}-\}$ eki getirilerek igele- meydana getirilmiştir. Brāhmī harfli metinlerde kelimenin kökü olan ige'nin iye şekline rastlanır: ev iyesi 'ev sahibi' (Gabain 1954: 71). Üstelik Türkçede kelime ortasında /g/ > /y/ değişimi bilindik bir seslik olaydır. Krş. Dîvânu Lugâti't-Türk eşgek > eşyek (Erdal 2004: 124), Kıpçakça egil- > eyil-, vs. (Karamanl1- 


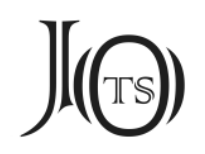

oğlu 1994: 1994). Ayrıca, eye ve eyele- bugün Türkmencede de mevcuttur. Dolayısıyla Eski Türkçede fiilin igele- ve iyele- gibi iki biçiminin olduğu düşünülebilir. Bu kelimeyi eyele- olarak okuyunca kelime başındaki /ey/'in ikiz ünlü olup olmadığı konusunda kesin bir şey söylemek zor, zira Eski Türkçenin yazı sistemleri bize bu konuda kesin bir delil sunmaktan acizdir. Ancak yazarın kullandığı Doerfer 1971'de /ia/ ikiz ünlüsünün İlk Türkçe (Urtürkisch) için tasarlandığını (439a) söylemeliyim.

Sözlükte ve sözlüğün dayandığı Xuanzang Biyografisi'nin VIII. cildindeki (Röhrborn 1994: 132, 241) AYALADAÇY’nın igele- ile ilgisinin kesin olmadığı belirtilmiştir. Bence Xuanzang Biyografisi'nde de kelime eyeledeçi şeklinde okunmalıdır. Kelime şöyle bir bağlamda geçiyor: hanıg eyeledeçi balık[ıg] énç kıltaçı yeu sün [a]tlıg beg bitidi. Burada \{-dAçI\} ekli eyele- fiili Yeu Süy, yani 姚嵩 Yaosong isimli bir beyin unvanını oluşturmuştur. Bu anlamda eyele- [ igele-] fiilinin metinde 'bir şeyi/kimseyi korumak' anlamında olduğu anlaşılmaktadır.

ig(i)dil- maddesinde (s. 114) vurgusuz orta hece ünlüsü /i/'nin düştüğü maddede zaten açıklanmıştır, bu nedenle maddenin igdil- şeklinde gösterilmesi daha doğrudur. Nitekim aslı *esştürüş- olan kelime doğru olarak maddede éştrüşolarak gösterilmiştir (s. 54).

il- maddesinde (s. 116) fiile şu anlamlar verilmiştir: 'mısra alıntı yapmak, örnek olarak alıntılamak; 2. hacı notu olarak yazmak, yerleştirmek; 3. evlat edinilmiş çocuğu kendine çekmek'. Verilen bu anlamlar, il-'in gerçek anlamı olan 'bir şeyi bir şeye bağlamak, tutturmak' anlamından çıkan anlamlardır. Bugün Türk dillerinde fiil asıl anlamıyla yaşamaktadır. Ancak sözlükte il-'in gerçek anlamını gösteren bir tanık zikredilmemiştir. CLAUSON, il- için 'to catch something with hand, a hook, a noose etc.' (1972: 125b) anlamını vermiş ve bu anlam için iki tanık zikretmiştir. Yazar, CLAUson'un zikrettiği anlamdaki tanıkları ya düzeltmiş ya da orijinal metindeki yerlerinin tahrip olduğunu söylemiş̧tir. Bu nedenle il-'in 'bir şeyi bir şeye bağlamak, tutturmak' anlamıyla ilgili bir tanığa sözlükte rastlanmaz. Eski Uygurcada fiilin bu anlamına rastlanmaması oldukça tuhaftır. Ancak bu durum başka bir sorunu da beraberinde getirmiştir, zira ilin- maddesinde (s. 118) fiilin yapısı izah edilirken dönüşlü gövdenin il- 'alıntılamak' köküne da- 


\section{J(৫)}

yandığı ifade edilmiştir, ama iliş- maddesinde (s. 123) işteş gövdenin tanıklanmamış '*asılmak, *tutunmak' anlamındaki il- fiiline dayandığı söylenmiştir. Hâlbuki ilin- ve iliş- fiillerinin ikisi de Dîvânu Lugâti't-Türk'teki il- 'bir şeyi bir şeye bağlamak, tutturmak' (Dankoff-Kelly 1982/I: 94 [178]) anlamındaki fiil köküne dayanmaktadır. Bu nedenle il-'in dönüşlü ve işteş gövdelerinin Dîvânu Lugâti't-Türk'teki il-ile ilişkilendirilmesi doğru olacaktır. Son olarak, il- için verilen 'evlat edinilmiş çocuğu kendine çekmek' anlamı yerine 'birinde istek uyandırarak kendisine ilgi, yakınlık duymasını sağlamak' veya ‘birini kendine bağlamak, birini kendisine yaklaştırmak' karşıllı̆̆ının düşünülmesinin daha uygun olacağı söylenebilir.

ilgeysöklen- maddesinde (s. 117) fiilin kökü ilgeysök'ün yuvarlak ünlüsünün geniş mi dar mı olduğu belirsizdir. Maddeye bunun hakkında küçük bir açıklama eklenmelidir.

isi- maddesinde (s. 128) fiilin sadece ön damak ünlülü şekli gösterilmiştir, ama Eski Uygurcada arka damak ünlülü biçimi de olabilir. Kelimenin kökeni hakkında bir izah için bk. Róna-Tas-Berta 2011/I: 472.

iske- maddesinde (s. 131) fiilin yapısı “iskeş-in fiil kökü” şeklinde açıklanmış ve Erdal 1991'deki iskeş-'e (558) bakılması söylenmiştir. Yazar, iske-'nin yapısına bir izah getirmek için fiilin işteş gövdesini zikretmiştir. CLAUson da fiilin yapısı hakkında bir şey söylememiştir (1972: 246b). Yazar, sözlüğünde ısır- isir- fiilinin tanıklanmamış bir *issi 'sıcak, 1sı' köküne dayandığını düşünmektedir (s. 95-96). Eğer ısır- isir- fiilinin kökeni hakkındaki bu öneriyi doğru kabul edecek olursak, iske-'nin de isig+e- > *isige- > isge- iske- şeklinde izahı da pekiala mümkün olacaktır. Nitekim iske-'nin anlamlarına bakıldığında bunların ısır- isir- ile büyük oranda benzeștiği görülmektedir: 'yırtmak, koparmak, vs.'. O hâlde, Eski Türkçede 'sıcak' anlamına gelen isig isminin üzerine isimleri fiilleştiren $\{+\mathrm{A}-\}$ ekinin getirilmesiyle iske-'nin türemiş olduğu tahmin edilebilir. Ancak bu köken önerisi kabul edildiğinde fiilin isge- şeklinde okunuşunun da mümkün olacağ1 hesaba katılmalıdır.

istet- maddesinde (s. 134-135) fiile verilen ikinci anlam olan 'pravāraṇa serenomisinde günahları ortaya çıartmak' yerine 'günah çıkartmak, günah itiraf ettirmek' karşıllı̆̆ daha anlaşılır olacaktır. 


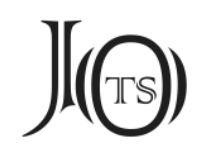

işleş- (s. 138-139) tanığında bazı sorunlar vardır. Fiile iki farklı anlam verilmiştir: '1. bir şey için, bir şeyde birlikte harekete geçmek, birlikte çalışmak' ve '2. kehanette bulunmak, önceden haber vermek (?)'. İki anlam arasından herhangi bir münasebet görmek neredeyse imkansız gibidir. Maddede gösterilen bazı örnekleri bu anlamlarda düşünmek de epey zor. Mesela, Xuanzang Biyografisi'nin IX. cildindeki terin nomta (...) artokrak terin işleş- (1197) cümlesinin tercümesi şüphe işaretiyle gösterilmiştir. Aynı şekilde, Xuanzang Biyografisi'nin VIII. cildindeki şu cümlenin tercümesi de yazar tarafından şüpheli bulunmuştur: kizleglig yayı üze işlemiş ol ertinü rrak (1240). Gösterilen iki cümlede de işleş- fiili Çince 期 qi (Giles 1964: 1030) karşllığındadır. Çince 期 qi karakteri 'tanımlamak, tahmin etmek, ummak' anlamındadır. Yukarıda şüpheli olarak gösterilen iki yerdeki işleş- fiili muhtemelen 'birlikte bir şey üzerinde yoğunlaşmak, odaklanmak' veya daha muhtemeleni 'bir şey/kişi üzerinde zihni teksif etmek' gibi bir anlamda olmalıdır. Bugün Türkiye Türkçesinde ve bazı Türk dillerinde işle- fiilinin 'içine girmek, nüfuz etmek' anlamına geldiği bilinmektedir. Şüpheli cümlelerin bağlamlarına önerdiğim anlamın gayet uygun olduğu söylenebilir. Bununla beraber, işle-'ye tereddütle verilen 'daimi yapmak, devamlı olarak yapmak, yoğun olarak yapmak, özenle yapmak (?)' (s. 138) anlamının da 'nüfuz etmek' olarak düşünülmesinin mümkün olabileceğini söyleyebilirim.

Sonuç olarak, elimizdeki çalışma ile Eski Uygurca söz hazinesinin bir miktarı daha gün yüzüne çıkmıştır. Sözlüğün müteakip ciltlerini sahanın uzmanlarının merakla beklediği şüphesizdir.

\section{Kaynakça}

Clauson, Sir G. (1972). An Etymological Dictionary of Pre-Thirteenth Century Turkish, Oxford: Oxford University Press.

DANKOFF, R. \& J. Kelly (1982). Mahmut el-Kāşgarī: Compendium of the Turkic Dialects (Dīvān Luүāt at-Türk) I, Harvard: Harvard University Press.

DOERFER, G. (1965). Türkische und Mongolische Elemente im Neupersischen, unter besonderer Berücksichtigung älterer Neupersischer Geschichtsquellen, vor allem der Mongolen- und Timuridenszeit II, Wiesbaden: Franz Steiner Verlag. 


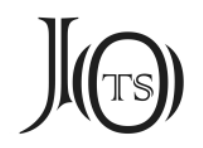

Doerfer, G. (1971). "Gedanken zur Gestaltung eines idealen Türkischen Etymologischen Wörterbuchs”, Orientalistische Literaturzeitung, 66/9-10: 437a-454b.

Doerfer, G. (1981). "Materialien zu türk. h- (I)”, Ural-altaische Jahrbücher Neue Folge, 1: 93-141.

Dotrfer, G. (1982). “Materialien zu türk. h- (II)”, Ural-altaische Jahrbücher Neue Folge, 2: 138-168.

ERDAL, M. (1991). Old Turkic Word Formation, a Functional Approach to the Lexicon I-II, Wiesbaden: Harrassowitz Verlag.

ERDAL, M. (2004). A Grammar of Old Turkic, Leiden-Boston: Brill.

GABAIN, A. von (1954). Türkische Turfan-Texte VIII: Texte in Brāhmīschrift, Berlin: Akademie Verlag.

GILES, A. H. (1964). A Chinese-English Dictionary I-II, Second Edition (Revised \& Enlarged. Shanghai-London 1912, Shanghai-London: Kelly and Walsh), Taipei: Literature House.

Hamilton, J. (1986). Manuscrits ouïgours du VIIIIe-Xe siècle de Touen-Houang I-II, Paris: Peeters.

HAMiLTON, J. R. (1971). Le conte bouddhique du bon et du mauvais prince en version ouïgoure: manuscrits ouïgours de Touen-Houang, Paris: Klincksieck.

KARAMANLIOĞLU, A. F. (1994). Kıpçak Türkçesi Grameri, Ankara: Türk Dil Kurumu Yayınları.

LigeTI, L. (1938). “Les voyelles longue en turc”, Journal Asiatique, 230: 177-204.

MORIYASU, T. (2019). Corpus of the Old Uighur Letters from the Eastern Silk Road, Berliner Turfantexte 46, Turnhout (Belgium): Brepols Publishers.

RAdLoff, W. (1893). Versuch eines Wörterbuches der Türk-Dialecte I, St. Petersburg: Tipografiya İmperatorskoy Akademii Nauk.

RAmSTeDt, G. R. (1916). “Zur Mongolisch-Türkischen Lautgeschichte III: der j-Iaut und damit zusammenhangende fragen”, Keleti Szemle, 16: 66-84.

RÖHRBORN, K. (1977). Uigurisches Wörterbuch, Sprachmaterial der vorislamischen türkischen Texte aus Zentralasien, Lieferung 1: a - agrıg, Wiesbaden: Franz Steiner Verlag. 


\section{J(৫)}

RöHRBORN, K. (1979). Uigurisches Wörterbuch, Sprachmaterial der vorislamischen türkischen Texte aus Zentralasien, Lieferung 2: agriglan - anta, Wiesbaden: Franz Steiner Verlag.

RöHRBORN, K. (1981). Uigurisches Wörterbuch, Sprachmaterial der vorislamischen türkischen Texte aus Zentralasien, Lieferung 3: anta (Schluß) - asanke, Wiesbaden: Franz Steiner Verlag.

RöHRBORN, K. (1987). Uigurisches Wörterbuch, Sprachmaterial der vorislamischen türkischen Texte aus Zentralasien, Lieferung 4: asankelig - ayat-, Wiesbaden: Franz Steiner Verlag.

RöHRBORN, K. (1994). Uigurisches Wörterbuch, Sprachmaterial der vorislamischen türkischen Texte aus Zentralasien, Lieferung 5: ayatil- - ämgäklig, Wiesbaden: Franz Steiner Verlag.

RöHRBORN, K. (1996). Die alttürkische Xuanzang-Biographie VIII, nach der Handschrift von Paris, Peking und St. Petersburg sowie nach dem Transkript von Annemarie v. Gabain, Wiesbaden: Harrassowitz Verlag.

RöHRBORN, K. (1998). Uigurisches Wörterbuch, Sprachmaterial der vorislamischen türkischen Texte aus Zentralasien, Lieferung 6: ämgäksin- - arnäk, Wiesbaden: Franz Steiner Verlag.

RöHRBORN, K. (2010). Uigurisches Wörterbuch, Sprachmaterial der vorislamischen türkischen Texte aus Zentralasien I/1: ab- äzüglä-, Stuttgart: Franz Steiner Verlag.

RöHRBORN, K. (2015). Uigurisches Wörterbuch, Sprachmaterial der vorislamischen türkischen Texte aus Zentralasie II/1: a-asvık, Stuttgart: Franz Steiner Verlag.

RöHRBORN, K. (2017). Uigurisches Wörterbuch, Sprachmaterial der vorislamischen türkischen Texte aus Zentralasie II/2: aš-äžük, Stuttgart: Franz Steiner Verlag.

RóNA-TAS, A. \& Á. BERTA (2011). West Old Turkic: TURKIC LOANWORDS in Hungarian III, Wiesbaden : Harrassowitz Verlag.

Tekin, T. (1994). “Türk Dillerinde Önseste y- Türemesi”, Türk Dilleri Araştırmaları, 4:51-66.

UÇAR, E. (2017a). “Altun Yaruk Sudur: VIII. Tegzinç, Yüce Sarasvatī (XV. Bölök, II. Kısım), Dede Korkut: Uluslararası Türk Dili ve Edebiyatı Araştırmaları Dergisi, 6/12:100150. 


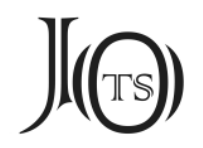

UçAR, E. (2017b). “Kutadgu Bilig Dizinindeki Bir Kelime Hakkında I: İlmek 〈inmek〉 Üzerine", Journal of Old Turkic Studies, 1/1: 128-144.

UÇAR, E. (2018a). “Kutadgu Bilig'in 221. Beyti Üzerine Düşünceler”, Dede Korkut: Uluslararası Türk Dili ve Edebiyatı Araştırmaları Dergisi, 7/15: 107-112.

UÇAR, E. (2018b). "Klaus RÖHRBORN. Uigurisches Wörterbuch, Sprachmaterial der vorislamischen türkischen Texte aus Zentralasien, Neubearbeitung, II. Nomina, Pronomina, Partikeln, Band 2: aš-ǎžük, Franz Steiner Verlag, Stuttgart, 2017, XXX+359 S. ISBN: 978-3-515-11862-0". Journal of Old Turkic Studies, 2/1: 141-144. (Tanitma)

UÇAR, E. (2020). “Türkiye'deki Eski Uygurca Metin Neşirleri İçin Kullanılacak Harfçevrim ve Yazıçevrim Kılavuzu”, Journal of Old Turkic Studies, 4/1: 231-250.

WILKENS, J. (2016). Buddhistische Erzählungen aus dem alten Zentralasien, Edition der altuigurischen Daśakarmapathāvadānamālā I-III, Berliner Turfantexte 37, Turnhout (Belgium): Brepols Publishers. 